\title{
KARAKTERISTIK PROSES HIDROKONVERSI KATALITIK DENGAN BAHAN BAKU BITUMEN
}

\author{
Yusnitati ${ }^{1)}$, Muhammad Hanif ${ }^{2}$, dan Adiarso ${ }^{3)}$ \\ 1) Pusat Teknologi Pengembangan Sumberdaya Energi \\ BPPT Gedung II Lantai 22 JI MH Thamrin no 8, Jakarta 10340 \\ ${ }^{2)}$ Laboratorium Pencairan Batubara, Puspiptek, Serpong \\ ${ }^{3)}$ Balai Rekayasa Desain dan Sistem Teknologi \\ E-mail: uniyus@yahoo.com; hanive@hotmail.com
}

\begin{abstract}
The effects of bitumen types in a hydro-conversion catalytic process to produce syntethic liquid fuels was investigated. Three samples of natural solid bitumen obtained from three different sampling points in Riau Province are used in this study. Preliminary technical feasibility of the natural solid bitumen as a feedstock of synthetic fuel oil using this process is also investigated. Experimental runs are carried out using a 1 liter stirred batch autoclave reactor under the standard conditions: reaction temperature of $450^{\circ} \mathrm{C}$, initial hydrogen pressure of $12 \mathrm{MPa}$ for 1 hour and atomic ratio of sulfur to iron at 2.0. This process condition is similar to direct coal liquefaction process using heavy oil solvent produced from Bench Scale Unit (BSU) $100 \mathrm{~kg} / \mathrm{hour}$ input in Takasago, Japan. The results indicate that the oil yield increases with the decrease of liquid bottom yield. Total $\mathrm{CO}+\mathrm{CO}_{2}$ and hydrocarbon gases products are almost equal at all bitumen samples. Due to their high ash content, the oil yield (LO, MO and HO) of bitumen samples relatively lower than the oil yield of coal liquefaction process. It was also found that $\mathrm{O} / \mathrm{C}$ and $\mathrm{H} / \mathrm{C}$ atomic ratio in bitumen samples vary significantly with their sampling point, but the $\mathrm{H} / \mathrm{C}$ ratio of bitumen relatively higher than typical coal. The higher of $\mathrm{H} / \mathrm{C}$ ratio, the easier of bitumen to be converted to synthetic fuel oil and leading to the more efficiently use of gaseous hydrogen. In conclusion, the natural solid bitumen has a possibility as a feedstock of synthetic fuel oil, if it is fed to the process in the form of a dried-ash-free-bitumen (hyperbitumen).
\end{abstract}

Kata kunci: bitumen, hidrokonversi katalitik, BBM sintetis

\section{PENDAHULUAN}

Penurunan produksi minyak bumi Indonesia yang belum memperlihatkan tanda-tanda perbaikan menyebabkan peningkatan jumlah impor minyak untuk memenuhi kebutuhan dalam negeri. Tidak hanya itu, tetapi peningkatan jumlah impor minyak juga disebabkan oleh peningkatan jumlah penduduk dan pertumbuhan ekonomi. Diperlihatkan pada Gambar 1 meningkatnya ketergantungan Indonesia terhadap impor minyak dari negara-negara lain. Terlihat bahwa pada tahun 2030 jumlah impor minyak mentah Indonesia akan naik 3 kali lipat dari impor tahun 2009 dengan defisit pasokan minyak total naik hingga 18 kali lipat dari 36 juta barel (2007) menjadi 657 juta barel (2030) atau naik dengan laju rata-rata $15,58 \%$ (Anonim., 2005; BPPT, 2010).
Jumlah defisit yang sedemikian banyak mendorong Indonesia untuk mencari dan meningkatkan peran energi alternatif seperti BBN atau BBM sintetis dari proses pencairan batubara.

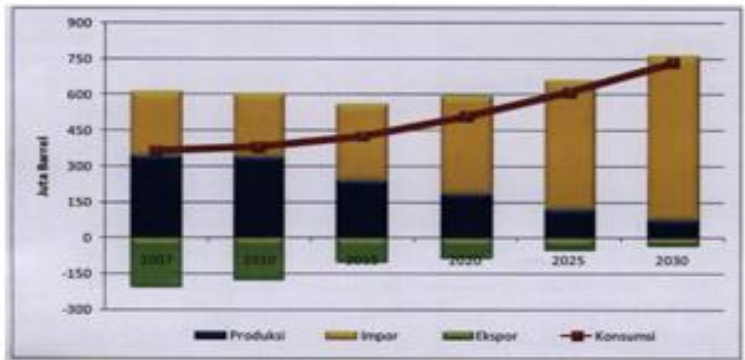

Sumber: Outlook Energi Indonesia 2010, BPPT

Gambar 1. Prakiraan produksi, impor, ekspor, konsumsi minyak total Indonesia 
Berbagai upaya telah dilakukan untuk menjamin ketersediaan energi domestik yang andal, aman, cukup, bersih dan berkelanjutan. Di antara upaya tersebut adalah menetapkan Kebijakan Energi Nasional (KEN) sebagai landasan bagi perencanaan strategis pengembangan energi yang komprehensif dan terpadu $^{[1]}$. Kebijakan tersebut dirangkum dalam program intensifikasi, diversifikasi dan konservasi energi. Bentuk implementasi kebijakan antara lain berupa pencarian sumber-sumber energi alternatif baik yang berbasis energi terbarukan maupun tak terbarukan.

Salah satu sumber energi alternatif yang menarik perhatian para peneliti dan kalangan industri adalah bitumen padat. Sementara itu, pengembangan potensi bitumen padat di Indonesia, sampai saat ini masih dalam tahap eksplorasi untuk kebutuhan inventarisasi dan pemanfaatannya skala komersial belum banyak dilakukan dalam.

Bitumen adalah sumber energi fosil yang banyak dijumpai dalam bentuk padatan dengan viskositas (derajat kekentalan), kandungan sulfur dan densitasnya relatif lebih tinggi daripada minyak bumi. Proses alami pembentukan bitumen, prinsipnya sama dengan proses pembentukan minyak bumi atau batubara. Semua sumber energi fosil tersebut adalah hasil dekomposisi timbunan mahluk hidup yang mati dan terpendam selama jutaan tahun. Namun, bitumen terbentuk lebih dulu daripada batubara.

Bahan bitumen hampir tidak pernah berdiri sendiri di alam. Sebagian besar bahan bitumen tercampur dengan residu minyak bumi dan bahan-bahan lain seperti bahan-bahan organik macam lilin (wax), mineral tanah lempung, senyawa hidrokarbon, dan/atau minyak-minyak berat yang berbentuk cair atau semi padat.

Bitumen didefinisikan oleh Murray R. Gray (1994) sebagai campuran alami hidrokarbon yang berbentuk padat atau semi padat. Lebih spesifik lagi, bitumen diklasifikasikan oleh UNITAR berdasarkan viskositas ( $>10^{5} \mathrm{MPa} . \mathrm{s}$ ), API Gravity $(<10)$ dan densitasnya $\left(>1.0 \mathrm{~g} / \mathrm{cm}^{3}\right)$. Sementara ASTM (American Standard for Testing Materials) berpendapat bahwa bitumen adalah nama suatu senyawa hidrokarbon tertentu yang berbentuk padat dengan ukuran partikel colloidal $(<1$ mikron atau $0,001 \mathrm{~mm}$ ) (Gray,Murray R.,1994).

Akibat karakteristiknya yang sedemikian, maka dari sisi teknis maupun ekonomis, pengolahan bitumen menjadi produk minyak menggunakan teknologi pengilangan minyak bumi yang konvensional (existing refinery) dianggap kurang layak, karena sulit untuk ditransportasikan melalui sistem perpipaan dan sifatnya juga sangat bervariasi. Oleh karena itu, satu-satunya pilihan teknologi yang mungkin diterapkan bagi pemanfaatan bitumen adalah dengan secara langsung ataupun tidak lansung menggunakannya sebagai sumber energi termal, yaitu sebagai bahan baku produksi bahan bakar minyak (BBM) sintetis.

Untuk upgrading bitumen secara prinsip digunakan konsep dasar yang sama dengan pencairan batubara, yaitu dengan proses-proses seperti pemutusan ikatan karbon-karbon dan karbon-sulfur yang terdapat dalam bitumen, peningkatan rasio atom $\mathrm{H} / \mathrm{C}$ produk setara dengan bahan bakar transportasi seperti minyak solar maupun bensin, serta penghilangan heteroatom $(\mathrm{O}, \mathrm{N}$ dan $\mathrm{S})$ dalam produk yang dihasilkan. $\mathrm{Di}$ antara proses yang dapat diterapkan untuk up-grading bitumen antara lain proses konversi termal (thermal conversion), proses konversi katalitik (catalytic conversion) dan proses konversi hidro (hydroconversion). Perbedaan proses-proses tersebut didasarkan pada produk yang dihasilkan, kondisi operasi, penggunaan katalis dan hidrogen (Tillman,D.A., 1991).

Dalam tulisan ini akan dibahas secara khurus proses konversi hidro-katalitik (hydroconversion catalytic) dengan bantuan pelarut yang bersifat donor hidrogen, yang merupakan semacam pelarut bagi bitumen. Pelarut donor hidrogen tersebut berperan menstabilkan pecahanpecahan (radikal bebas) yang dihasilkan dari perengkahan termal bitumen. Donor atom hidrogen untuk radikal bebas dapat berasal dari bitumen itu sendiri (hydrogen shuttling), dari pelarut, atau dari atom molekul hidrogen atmosfer. Sejumlah katalis juga ditambahkan dalam proses ini, berupa katalis sekali pakai (one-through catalyst) seperti katalis berbasis besi $\left(\mathrm{FeS}_{2}, \mathrm{Fe}_{2} \mathrm{O}_{3}\right.$ dan $\mathrm{FeOOH}$ ) yang banyak terdapat di alam, harganya relatif murah, serta mudah didapat. Dengan menambahkan katalis, diharapkan terjadi peningkatan perolehan minyak yang dihasilkan dan penyingkatan waktu reaksi yang dibutuhkan. Tidak hanya itu saja, tetapi katalis tersebut juga bermanfaat dalam menekan reaksi lanjut radikal bebas yang terbentuk dari proses termal dan reaksi dehidrogenasi dengan mengendalikan pembentukan kokas, menyediakan permukaan pengendapan metal, dan meningkatkan reaksi hidrogenasi (BPPTNEDO, 1997)

Pengujian dilaksanakan di Laboratorium Pencairan Batubara BPPT, dalam Kawasan PUSPIPTEK, Serpong, Tangerang. Riset ini dilaksanakan memanfaatkan fasilitas reaktor labscale autoclave kapasitas 1 liter tipe batch yang berfungsi sebagai reaktor unggun slurry (slurry- 
bed reactor), dimana semua umpan seperti bitumen, katalis, pelarut dan gas hidrogen direaksikan secara simultan. Proses ini dimodifikasi dari proses pencairan batubara yang diaplikasikan untuk bitumen atau residu padat yang mengandung padatan atau mineral yang relatif tinggi.

\section{BAHAN DAN METODE}

\subsection{Bitumen Padat}

Dalam penelitian ini digunakan sampel bitumen padat yang berasal dari tiga titik lokasi pengambilan sampel di daerah Riau. Karakteristik dari ketiga sampel bitumen padat tersebut seperti ditunjukkan pada Tabel 1.

Tabel 1. Karakteristik sampel bitumen padat

\begin{tabular}{|l|l|l|l|}
\hline \multicolumn{1}{|c|}{ Parameter } & Bit. A & Bit. B & Bit. C \\
\hline Proksimat (\% berat adb) & & & \\
Moisture & 1,52 & 1,66 & 3,49 \\
Ash & 90,33 & 90,31 & 79,45 \\
Volatile Matter & 6,41 & 6,56 & 15,12 \\
Fixed Carbon & 1,74 & 1,47 & 1,94 \\
\hline Ultimat (\% berat daf) & & & \\
Carbon & 51,17 & 52,05 & 61,96 \\
Hydrogen & 7,61 & 7,85 & 10,08 \\
Nitrogen & 1,96 & 1,99 & 1,88 \\
Total Sulfur & 2,33 & 3,86 & 2,46 \\
Oxygen & 36,93 & 34,25 & 23,62 \\
\hline
\end{tabular}

Sebelum diumpankan ke dalam autoclave, bitumen digiling terlebih dahulu hingga lolos 200 mesh dan dikeringkan hingga kandungan airnya sekitar $10 \%$ berat. Bitumen kemudian disimpan dalam wadah tertutup agar terhindar dari penyerapan air dari udara terbuka.

\subsection{Pelarut}

Untuk keperluan penelitian, digunakan pelarut fraksi berat (heavy fraction) dengan titik didih yang berkisar antara $300-420^{\circ} \mathrm{C}$ dan detail karakteristik seperti pada Tabel 2. Fraksi pelarut diperoleh dari distilasi vakum $10 \mathrm{mmHg}$ di laboratorium pencairan batubara. Pelarut BSU diperoleh dari TCLC (Takasago Coal Liquefaction Center) Jepang. Pelarut BSU tersebut diperoleh dari unit BSU (Bench Scale Unit) kapasitas 100 $\mathrm{kg} / \mathrm{jam}$ di Takasago dengan menggunakan batubara Banko. Pelarut yang sama juga digunakan untuk membuat katalis slurry.

Tabel 2. Karakteristik pelarut minyak fraksi berat

\begin{tabular}{|l|l|l|l|l|c|}
\hline \multicolumn{5}{|c|}{ Ultimat (\%berat daf) } & $\begin{array}{c}\text { Rasio } \\
\text { Atom }\end{array}$ \\
\hline C & H & N & S & O diff. & H/C \\
\hline $\begin{array}{l}88, \\
4\end{array}$ & 8,5 & 1,0 & 0,1 & 2,0 & 1,154 \\
\hline
\end{tabular}

\subsection{Katalis}

Katalis yang digunakan dalam studi ini adalah katalis limonit alami berbasis besi yang berasal dari Soroako, Sulawesi Selatan. Katalis tersebut adalah katalis yang telah digunakan sebagai katalis standar di Laboratorium Pencairan Batubara BPPT. Berdasarkan hasil pengujian yang telah dilakukan sebelumnya, katalis limonit memiliki aktivitas yang sangat baik dibandingkan katalis besi lainnya. Adapun karakteristik katalis (berupa slurry) dapat dilihat pada Tabel 3.

Tabel 3. Karakteristik katalis limonit slurry

\begin{tabular}{|c|c|c|c|l|l|l|}
\hline \multicolumn{7}{|c|}{ Komposisi Logam (\% berat kering) } \\
\hline $\mathrm{Fe}$ & $\mathrm{Mg}$ & $\mathrm{Al}$ & $\mathrm{Si}$ & $\mathrm{Mo}$ & $\mathrm{Ni}$ & $\mathrm{S}$ \\
\hline 46.96 & 0.08 & 3.35 & 2.64 & 0.09 & 1.29 & 0.00 \\
\hline
\end{tabular}

Sebelum digunakan, padatan limonit digiling dengan pelarut fraksi berat (Tabel 2) dengan perbandingan 30:70 untuk mencegah oksidasi katalis oleh udara dan menciptakan efek terdispersi yang lebih baik. Penggilingan menggunakan Eiirich Tower Mill (ø 165 mm) sistem batch yang dilengkapi dengan zirconia ball (ø $1 \mathrm{~mm}$ ) dan vessel (vol. 6,8 L, SUS 304) pada kecepatan 1000 rpm selama 3 jam, sehingga menghasilkan katalis dalam bentuk slurry dengan ukuran diameter partikel sekitar 0,5-0,8 $\mu \mathrm{m}$.

Jadi katalis yang dimasukkan ke reaktor berbentuk slurry, yang dibuat dengan cara menggerus katalis padat tersebut di dalam pelarut dengan menggunakan tower mill dengan teknik seperti telah diterangkan sebelumnya. Waktu yang diperlukan untuk membuat katalis slurry ditentukan selama 3 jam atau lebih dengan perkiraan bahwa waktu penggerusan tersebut cukup untuk menghasilkan katalis dengan ukuran diameter partikel sekitar 0,5-0,8 $\mu \mathrm{m}$.

\subsection{Metode Pengujian}

Pengujian proses hidrokonversi katalitik bitumen padat dilakukan menggunakan reaktor autoclave kapasitas 1 liter tipe batch yang dilengkapi pemanas (electric furnace window type) pada kecepatan pemanasan $284{ }^{\circ} \mathrm{C} / \mathrm{jam}$, dan pengaduk (inductive agitator) dengan kecepatan pengadukan $1000 \mathrm{rpm}$, seperti yang terlihat pada Gambar 2. Sedangkan kondisi operasi pengujian dapat dilihat pada Tabel 4. 


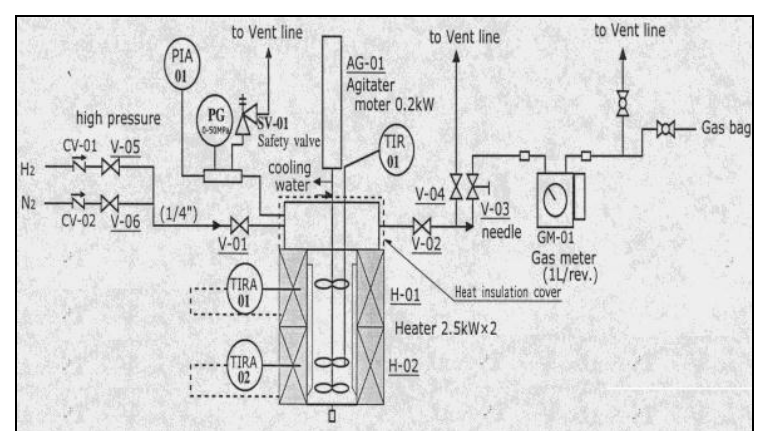

Gambar 2. Skema Autoclave kapasitas 1 liter

Tabel 4. Kondisi operasi pengujian

\begin{tabular}{|c|c|c|c|c|}
\hline $\begin{array}{c}\text { Temp. } \\
\text { Reaksi } \\
{\left[{ }^{\circ} \mathrm{C}\right]}\end{array}$ & $\begin{array}{c}\text { Tekanan } \\
\text { Awal } \\
{[\mathrm{MPa}]}\end{array}$ & $\begin{array}{c}\text { Waktu } \\
\text { Reaksi } \\
{[\mathrm{min}]}\end{array}$ & $\begin{array}{c}\text { Kons. } \\
\text { Katalis } \\
{[\% \text { berat] }}\end{array}$ & $\begin{array}{c}\mathrm{S} / \mathrm{Fe} \\
{[\text { rasio atom] }}\end{array}$ \\
\hline 450 & 12 & 60 & 3 & $2 / 1$ \\
\hline
\end{tabular}

Setelah seluruh umpan (serbuk bitumen, pelarut, katalis slurry dan sulfur) dimasukkan ke dalam autoclave dan ditutup, kemudian dilakukan pembilasan. Pertama dialirkan gas nitrogen bertekanan $20-30 \mathrm{~kg} / \mathrm{cm}^{2}$ ke dalam autoclave sebanyak tiga kali untuk menghilangkan oksigen di dalam autoclave. Kemudian dialirkan gas hidrogen hingga tekanan sekitar $20-30 \mathrm{~kg} / \mathrm{cm}^{2}$ untuk membersihkan ruangan di dalam autoclave dari konsentrasi udara (nitrogen dan oksigen). Pembilasan dengan hidrogen ini juga dilakukan sebanyak tiga kali.

Setelah proses pembilasan selesai dilakukan tes kebocoran dengan mengalirkan gas hidrogen pada tekanan $200 \mathrm{~kg} / \mathrm{cm}^{2}$ ke dalam autoclave dan ditahan selama semalam untuk mengetahui apakah ada kebocoran dengan indikasi terjadinya penurunan tekanan. Test kebocoran juga dilakukan dengan menggunakan hydrogen gas detector atau dengan penyemprotan air sabun ke tempat kemungkinan terjadinya kebocoran. Jika tidak terjadi kebocoran, tekanan gas hidrogen diturunkan sampai tekanan gas yang ditentukan dan autoclave siap untuk dioperasikan. Kemudian, aliran air pendingin untuk pengaduk, termokopel dan kontrol panel siap dioperasikan.

Kecepatan pemanasan sistem autoclave 1 liter di laboratorium Pencairan Batubara BPPT adalah $284^{\circ} / \mathrm{jam}$. Setelah suhu cairan mencapai $450^{\circ} \mathrm{C}$, waktu reaksi mulai dihitung. Waktu reaksi 1 jam.

Setelah proses reaksi, selesai, produk cairan dipisahkan menggunakan metode distilasi vakum untuk mendapatkan fraksi $\mathrm{H}_{2} \mathrm{O}$, fraksi minyak dengan titik didih $\mathrm{C}_{5}-420^{\circ} \mathrm{C}$ dan fraksi coal liquid bottom (CLB) dengan titik didih di atas $420^{\circ} \mathrm{C}$.

Produk gas diambil pada tiga kondisi tekanan autoclave yang mewakili yaitu 5,3 dan $1 \mathrm{MPa}$. Analisis dilakukan untuk masing-masing kondisi tersebut menggunakan gas kromatographi. Konsentrasi gas $\mathrm{H}_{2}, \mathrm{CO}$ dan $\mathrm{CO}_{2}$ dianalisa menggunakan Shimazdu GC-8A, Thermal Conductivity Detector dengan kolom dioctyl phtalete $4 \mathrm{~m} \times 3 \varnothing$, temperatur $100{ }^{\circ} \mathrm{C}$ dan argon sebagai gas pembawa (carrier gas). Konsentrasi gas hidrokarbon $\left(\mathrm{C}_{1}-\mathrm{C}_{4}\right)$ dianalisa menggunakan Yanaco GC-2800, Flame Ionization Detector dengan kolom porapak-Q $2 m \times 3 \varnothing$, temperatur $140{ }^{\circ} \mathrm{C}$ dan nitrogen sebagai carrier gas. Sedangkan, konsentrasi gas $\mathrm{H}_{2} \mathrm{~S}$ diperoleh menggunakan tube gas analyzer, Gastec Dragger. Semua yield ditentukan dalam basis bitumen kering bebas abu. Skema metode pengujian dan analisis tampak pada Gambar 3.

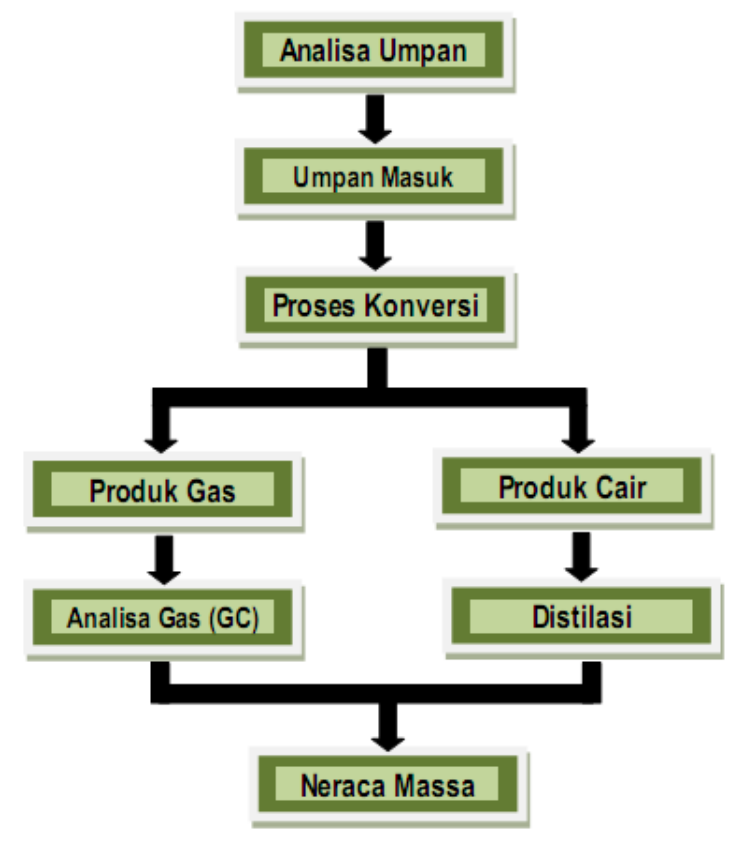

Gambar 3. Skema metode pengujian dan analisis

\subsection{Metode Analisis}

Standar analisis yang dipakai untuk analisis proksimat adalah ASTM D 3173 (moisture), ASTM D 3174 (ash), dan ASTM D 3175 (volatile metter). Kandungan unsur-unsur di atas dinyatakan sebagai persen berat. Kandungan fixed carbon ditentukan secara by difference yakni: (100 - VM - Ash- Moisture) dalam persen berat. Analisis ultimat, untuk menentukan kandungan $\mathrm{C}, \mathrm{H}$, dan $\mathrm{N}$ ditentukan menurut ASTM D5291/D5373, sedangkan total S menurut ASTM D1552/D4292. Kandungan O ditentukan secara by defference, yakni : $(100-\mathrm{C}-\mathrm{H}-\mathrm{N}-$ S) dalam persen berat. Analisis komposisi mineral/oksida logam menggunakan standar analisis ASTM D 3682, ASTM D 2795, dan ASTM D 1757. 


\section{HASIL DAN PEMBAHASAN}

\subsection{Pengaruh Komposisi Produk Gas}

Pada Gambar 4 diperlihatkan pengaruh komposisi produk gas hasil proses hidrokonversi katalitik dari ketiga sampel bitumen. Dari hasil yang didapatkan terlihat bahwa bitumen jenis $A$ menghasilkan presentase total komposisi gas $\mathrm{CO}+\mathrm{CO}_{2}$ relatif lebih rendah dibandingkan bitumen jenis B dan C. Sementara itu, hasil analisis ultimat menunjukkan rasio $\mathrm{O} / \mathrm{C}$ dari bitumen bervariasi $(0,29$ sampai 0,54$)$. Nilai rasio $\mathrm{O} / \mathrm{C}$ tersebut berbanding lurus dengan tingkat pembentukan gas-gas $\mathrm{CO}$ dan $\mathrm{CO}_{2}$. Pembentukan produk gas-gas $\mathrm{CO}$ dan $\mathrm{CO}_{2}$ tidak diinginkan dalam proses ini karena akan mengurangi tingkat perolehan minyak.

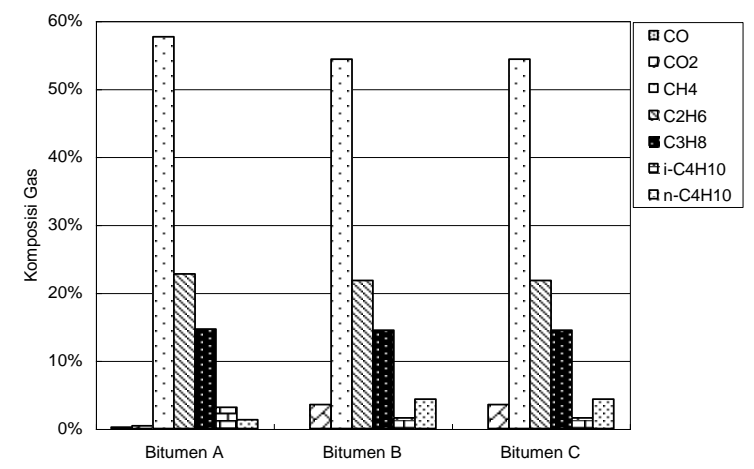

Gambar

4.

Komposisi gas hasil pengujianupgrading bitumen

Diketahui presentase total komposisi gas hidrokarbon dari ketiga jenis bitumen A, B dan C relatif hampir sama, kecuali untuk bitumen jenis A dimana gas $\mathrm{CH}_{4}$ relatif sedikit lebih tinggi. Dari hasil analisis ultimat ketiga sampel bitumen mencirikan rasio atom $\mathrm{H} / \mathrm{C}$ yang bervariasi $(1,78$ sampai 1,95). Hal ini menguntungkan dalam proses upgrading karena mengindikasikan kemudahan bitumen untuk dicairkan menjadi minyak sintetis maupun gas dan konsumsi hidrogen sedikit karena hidrogen yang dikandung bitumen dapat menjadi donor bagi dirinya sendiri dalam stabilisasi produk minyak.

\subsection{Pengaruh Distribusi Produk Minyak}

Gambar 5 menunjukkan pengaruh distribusi perolehan produk minyak hasil pengujian proses hidrokonversi katalitik bitumen.

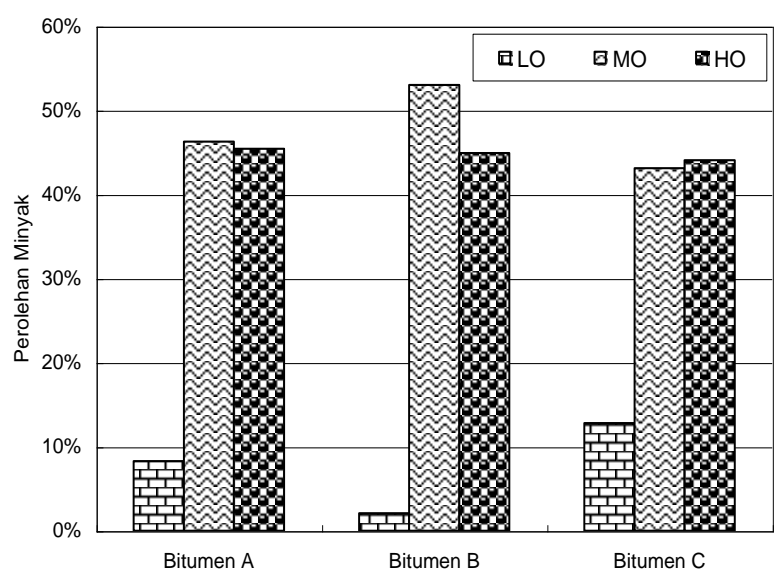

Gambar 5. Distribusi perolehan minyak hasil pengujian upgrading bitumen

Produk minyak dipisahkan dalam tiga kategori, yaitu LO-light oil (minyak ringan), MOmiddle oil (minyak menengah) dan HO-heavy oil (minyak berat) melalui proses distilasi secara vakum.

Hasil ini menunjukkan bahwa presentase perolehan minyak ringan (LO) dari bitumen jenis C relatif lebih tinggi sekitar $13 \%$ dibandingkan bitumen A (sekitar 9\%) dan bitumen B (sekitar 4\%). Presentase perolehan minyak menengah (MO) dari bitumen $\mathrm{B}$ relatif lebih tinggi (sekitar $53 \%$ ) dibandingkan bitumen A dan C. Sedangkan presentase perolehan minyak berat $(\mathrm{HO})$ dari ketiga jenis bitumen relatif hampir sama.

\subsection{Pengaruh Distribusi Produk Total}

Gambar 6 menunjukkan distribusi perolehan produk hasil pengujian upgrading bitumen. Untuk mengevaluasi kemampuan bitumen terkonversi menjadi produk minyak dan gas, maka sebagai basis perhitungan perolehan minyak dan gas tersebut digunakan $w t \%$ daf (persen berat batubara kering bebas abu).

Perolehan gas dari bitumen jenis $C$ (sekitar $12 \%$ berat daf) relatif sedikit lebih tinggi dibandingkan bitumen jenis A dan B (sekitar 10 \%berat daf). Sedangkan perolehan minyak dari bitumen jenis A relatif lebih tinggi sekitar 53 \%berat daf, diikuti dengan bitumen B sekitar 43 \%berat daf dan kemudian bitumen C sekitar 47 \%berat daf. Perolehan residu (bitumen liquid bottom-BLB) berbanding terbalik dengan perolehan minyak untuk masing-masing jenis bitumen, kecuali untuk bitumen $B$. 


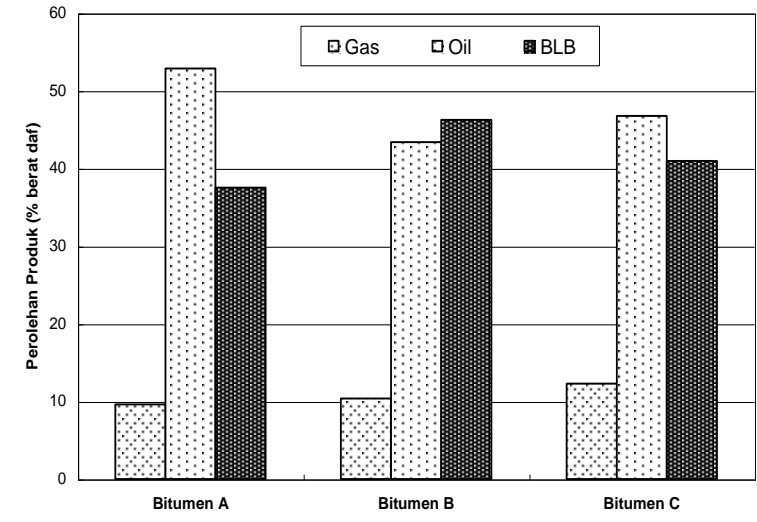

Gambar 6. Distribusi perolehan produk hasil pengujian upgrading bitumen

\subsection{Evaluasi Kelayakan Teknis Bitumen sebagai Bahan Baku BBM Sintetis}

Kelayakan teknis bitumen sebagai bahan baku BBM sintetis dievaluasi berdasarkan data hasil analisis karakteristik bitumen dan data hasil pengujian. Hasil analisis bitumen dalam hubungannya sebagai bahan baku proses upgrading untuk memproduksi minyak sintetis diberikan pada Tabel 5.

Ketiga sampel bitumen mencirikan rasio (atom) hidrogen $(\mathrm{H})$ terhadap karbon $(\mathrm{C})$ yang tinggi, yaitu sebesar 1,78 untuk sampel bitumen A, 1,81 (sampel B), dan 1,95 (sampel C), jauh lebih tinggi dari rasio $\mathrm{H} / \mathrm{C}$ bitumen pada umumnya yang berkisar 1,5. Hal ini menguntungkan dalam proses upgrading karena mengindikasikan kemudahan bitumen untuk dicairkan menjadi minyak sintetis maupun gas dan konsumsi hidrogen sedikit karena hidrogen yang dikandung bitumen dapat menjadi donor dirinya dalam stabilisasi produk minyak.

Tabel 5. Bitumen sebagai bahan baku BBM sintetis

\begin{tabular}{|l|c|c|c|}
\hline \multicolumn{1}{|c|}{ Parameter } & Bit. A & Bit. B & Bit. C \\
\hline Rasio atom H/C & 1,78 & 1,81 & 1,95 \\
\hline Rasio atom O/C & 0,54 & 0,46 & 0,29 \\
\hline Air (\% as received) & 6,83 & 6,83 & 11,16 \\
\hline Abu(\% as received) & 85,46 & 85,73 & 73,14 \\
\hline Sulfur (\% as received) & 0,18 & 0,29 & 0,39 \\
\hline
\end{tabular}

Sementara itu, kandungan oksigen dalam bitumen sangat bervariasi, rata-rata di atas batubara dengan harga 0,29 sampai $0,54 \%$ berat. Rasio O/C yang tinggi memberikan indikasi tingkat pembentukan gas-gas $\mathrm{CO}, \mathrm{CO}_{2}$ dan $\mathrm{H}_{2} \mathrm{O}$ yang tinggi pula. Pembentukan produk gas-gas $\mathrm{CO}$ dan $\mathrm{CO} 2$ dan air tidak diinginkan dalam proses pencairan batubara karena akan mengurangi tingkat perolehan minyak. Kandungan sulfur bitumen relatif rendah untuk rata-rata bitumen menurut literatur. Kandungan sulfur yang rendah tidak berpengaruh secara langsung dalam proses upgrading, tetapi kandungan sulfur yang tinggi dapat memberikan pengaruh positif terhadap aktivasi katalis. Kandungan abu bitumen juga sangat tinggi, kandungan abu tersebut berpengaruh negatif karena dapat menyebabkan pengerakan dan deaktivasi katalis, penyumbatan, selain itu biaya yang dibutuhkan untuk penghilangan abu menjadi sangat tinggi selain presentase rekoveri minyak menjadi sangat kecil.

Dari beberapa alternatif teknologi upgrading seperti yang diuraikan di atas yang meliputi proses termal, proses katalitik dan proses konversi hidro maka proses konversi hidro yang lebih baik ditinjau dari konversi dan kualitas minyak sintetis yang dihasilkan. Proses termal memiliki keunggulan dari segi kesederhanaan proses serta biaya operasinya, tetapi kualitas produk maupun perolehan produk minyak yang dihasilkan sangat rendah. Proses katalitik dapat meningkatkan kualitas produk cair maupun gas yang dihasilkan. Produk kokas yang merupakan hasil samping dari kedua proses ini juga tidak baik karena kokas yang terbentuk bercampur dengan abu bitumen yang sangat tinggi. Dengan demikian produk kokas dengan pemanfaatan bitumen ini tidak bisa digunakan dan hanya produk gas dan minyak saja dengan jumlah yang relatif kecil. Hal ini bisa disimpulkan bahwa proses termal dan katalitik tidak layak untuk memproduksi minyak maupun kokas dari bitumen uji.

Hal yang sama juga berlaku pada proses konversi hidro dimana produk minyak yang merupakan produk utama dari proses ini tidak akan banyak mengingat abu yang terkandung dalam bitumen sangat tinggi. Hasil kajian kelayakan teknis menunjukkan bahwa potensi bitumen padat sebagai bahan baku BBM sintetis akan menghasilkan perolehan minyak yang lebih tinggi jika umpan yang digunakan dalam proses adalah bitumen kering bebas abu.

\section{KESIMPULAN}

Dari bitumen jenis A dihasilkan presentase total komposisi gas $\mathrm{CO}+\mathrm{CO}_{2}$ yang relatif lebih rendah daripada bitumen jenis B dan C. Sementara itu, hasil analisis ultimat menunjukkan rasio $\mathrm{O} / \mathrm{C}$ dari bitumen bervariasi $(0,29$ sampai 0,54$)$. Rasio $\mathrm{O} / \mathrm{C}$ ini secara linear mengindikasikan tingkat pembentukan gas-gas $\mathrm{CO}, \mathrm{CO}_{2}$. Dalam proses ini, pembentukan gas-gas $\mathrm{CO}$ dan $\mathrm{CO}_{2}$ harus dihindari karena dapat mengurangi perolehan jumlah produk minyak. Sedangkan presentase total komposisi gas hidrokarbon dari ketiga jenis bitumen $\mathrm{A}, \mathrm{B}$ dan $\mathrm{C}$ relatif hampir sama, kecuali 
untuk bitumen jenis $\mathrm{A}$ dimana gas $\mathrm{CH}_{4}$ relatif sedikit lebih tinggi.

Dalam hal jumlah/persentase perolehan minyak ringan (LO), bitumen jenis C perolehannya relatif lebih tinggi yaitu sekitar $13 \%$ daripada bitumen jenis A (sekitar 9\%) dan bitumen jenis B (sekitar 4\%). Sedangkan dalam hal persentase perolehan minyak menengah (MO), bitumen jenis B jumlah perolehannya relatif lebih tinggi (sekitar 53\%) daripada bitumen jenis A dan C. Persentase perolehan minyak berat (HO) dari ketiga jenis bitumen, sementara itu, relatif hampir sama.

Dari konversi sampel bitumen padat yang diuji, perolehan minyak (LO, MO, $\mathrm{HO}$ ) relatif lebih rendah daripada perolehan minyak dari proses pencairan batubara pada umumnya. Mengingat tingginya kandungan abu dalam bitumen, kenaikan perolehan minyak akan menurunkan perolehan residu (bitumen liquid bottom).

Total komposisi gas $\mathrm{CO}+\mathrm{CO}_{2}$ dan hidrokarbon dari ketiga sampel bituman yang diuji hampir sama satu sama lain. Rasio O/C dari bitumen bervariasi dan rasio atom $\mathrm{H} / \mathrm{C}$ relatif tinggi. Hal ini mengindikasikan mudahnya pencairan bitumen menjadi minyak sintetis maupun gas serta sedikitnya konsumsi hidrogen karena kandungan hidrogen dalam bitumen dapat menjadi donor bagi bitumen dalam stabilisasi produk minyak.

Dari hasil kajian kelayakan teknis ditemukan bahwa bitumen padat sebagai bahan baku BBM sintetis berpotensi untuk menghasilkan perolehan minyak yang lebih tinggi jika menggunakan umpan bitumen kering bebas abu di dalam prosesnya.

\section{DAFTAR PUSTAKA}

Anonim., 2005. Blueprint Pengelolaan Energi Nasional. 2005-2025, Jakarta

BPPT-NEDO, 1997. Applicability Study on Direct Liquefaction of Banko Coal in Indonesia. Proceeding of Bilateral Seminar JapanIndonesia on Coal Liquefaction. BPPT Jakarta. Indonesia

BPPT, 2010. Outlook Energy Indonesia 2010. Teknologi untuk mendukung keandalan pasokan energy listrik. Jakarta, Agustus

Gray,Murray R.,1994. Upgrading Petroleum Residues and Heavy Oils. Marcel Dekker, Inc., New York.

Tillman,D.A., 1991. The combustion Solid Fuels and Wastes. Academic Press, Inc., California. 